\title{
Determinan Hipertensi pada Lansia di Puskesmas Sidomulyo Kota Pekanbaru
}

\author{
Liva Maita \\ Program Studi Kebidanan, STIKes Hang Tuah Pekanbaru \\ E-mail: livamaita@gmail.com
}

\begin{abstract}
Hypertension Determinan In the Elderly at Sidomulyo Health Center Pekanbaru City. Hypertension is a condition in which a person has an elevated blood pressure above normal which is indicated by systolic number $\geq 140 \mathrm{mmHg}$ and diastolic $\geq 90 \mathrm{mmHg}$. Based on the Health Profile of Riau Province in 2010 the incidence of hypertension ranks first of 10 most common diseases, namely $27.3 \%$. The purpose of this study to determine the determinant factors of hypertension in elderly in Puskesmas Sidomulyo Pekanbaru. The type of this research is quantitative analytical research with cross sectional design. Population amounted to 4.101 people with a sample of 176 people.Teknik sampling used purposive sampling. Data analysis in this research is multivariate analysis using multiple logistic regression test. The results of this study indicate that there is a correlation of hypertension history with hypertension occurrence with $\mathrm{p}$ value $0,001(<0,05)$, OR $95 \%$ CI $13,3(5,74$ to 30,93$)$. Health workers are expected to perform routine blood pressure checks on the elderly, providing information, education and health promotion about hypertension.
\end{abstract}

Keywords: History of hypertension, Hypertension

\begin{abstract}
Abstrak: Determinan Hipertensi pada Lansia di Puskesmas Sidomulyo Kota Pekanbaru. Hipertensi adalah suatu kondisi dimana seseorang mengalami peningkatan tekanan darah di atas normal yang ditunjukkan dengan angka sistolik $\geq 140 \mathrm{mmHg}$ dan diastolik $\geq 90 \mathrm{mmHg}$. Berdasarkan Profil Kesehatan Provinsi Riau tahun 2010 kejadian hipertensi menempati urutan pertama dari 10 penyakit yang paling umum, yaitu 27,3\%. Tujuan dari penelitian ini untuk mengetahui faktor determinan terjadinya hipertensi pada lansia di Puskesmas Sidomulyo Pekanbaru. Jenis penelitian ini adalah penelitian analitik kuantitatif dengan rancangan cross sectional. Populasi berjumlah 4.101 orang dengan sampel yang berjumlah 176 orang.Teknik sampling yang digunakan purposive sampling. Analisa data pada penelitian ini yaitu analisa multivariat menggunakan uji regresi logistik berganda. Hasil penelitian ini menunjukkan terdapat hubungan riwayat hipertensi dengan kejadian hipertensi dengan nilai $p 0,001(<0,05)$, OR 95\% CI 13,3 (5,74 sampai 30,93). Petugas kesehatan diharapkan melakukan pemeriksaan rutin tekanan darah kepada lansia, memberikan informasi, edukasi serta promosi kesehatan tentang hipertensi.
\end{abstract}

Kata kunci: Riwayat hipertensi, Hipertensi

Hipertensi merupakan salah satu penyakit degeneratif yang mempunyai tingkat morbiditas dan mortalitas tinggi dimana sering ditemukan pada usia lanjut yang peningkatan abnormal tekanan darah, baik tekanan darah sistolik maupun tekanan darah diastolik. Hipertensi terjadi pada tekanan darah adalah $\geq 140 \mathrm{mmHG}$ (tekanan sistolik) dan $\geq 90 \mathrm{mmHG}$ (tekanan diastolik). Pembuluh darah arteri kehilangan kelenturannya dan menjadi kaku, sehingga tidak dapat mengembang pada saat jantung memompa darah yang menyebabkan naiknya tekanan yang dimaksudkan terjadi pada usia lanjut, dimana dinding arterinya telah menebal dan kaku karena arteriosklerosis (Hariwijaya, 2007).

Hipertensi memang dapat dikatakan sebagai pembunuh diam-diam atau the silent killer. Pada umumnya terjadi tanpa gejala (asimptomatis). Sebagian besar orang tidak merasakan apa pun, meski tekanan darahnya sudah jauh di atas normal (Hartono, 2011). Hipertensi mempunyai risiko besar pada kematian karena komplikasi kardiovaskuler seperti stroke, jantung, atau gagal ginjal apabila tidak ditangani dengan baik. Hipertensi dapat menyerang laki-laki maupun perempuan, dan kejadian ini sering terjadi pada usia >55 tahun (Wahda, 2011).

Penderita hipertensi di Indonesia diperkirakan 15 juta tapi hanya $4 \%$ yang controlled hypertension (hipertensi terkontrol) dan sebesar $50 \%$ penderita tidak menyadari diri sebagai penderita hipertensi sehingga cenderung untuk menderita hipertensi yang lebih berat karena penderita tidak berupaya 
mengubah dan menghindari faktor risiko (Bustan, 2007).

Hipertensi dapat dipicu oleh 2 faktor yaitu faktor yang tidak dapat dikontrol (seperti: umur, jenis kelamin, dan faktor genetik) dan faktor yang dapat dikontrol (seperti: obesitas, aktifitas fisik, merokok, pola konsumsi garam, stres). Hipertensi seringkali tidak menimbulkan gejala, sementara tekanan darah yang terus menerus tinggi dalam jangka waktu lama dapat menimbulkan komplikasi (Indriyani, 2009).

Data Dinas Kesehatan Kota Pekanbaru dari 20 puskesmas yang ada, ternyata Puskesmas Sidomulyo pada tahun 2013 menempati urutan pertama kunjungan hipertensi lansia terbanyak yaitu 2024 kasus $(49,35 \%)$.

\section{METODE}

Jenis penelitian ini adalah observasional analitik dengan menggunakan desain penelitian cross sectional. Populasi dalam penelitian ini adalah seluruh lansia berusia $\geq 60$ tahun yang berada di Wilayah kerja Puskesmas Sidomulyo sebanyak 4101 orang. Sampel dalam penelitian ini sebanyak 176 orang. Teknik sampling yang digunakan purposive sampling. Analisis data dilakukan secara multivariat menggunakan uji regresi logistik berganda.

\section{HASIL}

\section{A. ANALISIS UNIVARIAT}

Tabel 1. Distribusi Karakteristik Lansia menurut Kejadian Hipertensi

\begin{tabular}{lcc}
\hline \multicolumn{1}{c}{ Variabel } & n & \% \\
\hline Pola konsumsi garam & & \\
\hline < 1 sendok teh & 81 & 46,0 \\
$\geq 1$ sendok teh & 95 & 54,0 \\
\hline Indeks Masa Tubuh & & \\
\hline Obesitas & 90 & 51,1 \\
Tidak obesitas & 86 & 48,9 \\
\hline Kebiasaan Merokok & & \\
\hline Ya ( $\geq$ 1btg/hari) & 95 & 54,0 \\
Tidak & 81 & 46,0 \\
\hline Aktifitas Fisik & & \\
\hline$\geq 3$ kali & 82 & 46,6 \\
<3 kali & 94 & 53,4 \\
\hline
\end{tabular}

Pada tabel 1 dapat diketahui bahwa lansia mengkonsumsi garam $\geq 1$ sendok teh (54\%), Indeks masa tubuh (IMT) lansia yang mengalami obesitas (51,1\%), Lansia yang memiliki kebiasaan merokok lebih dari satu batang perhari
(54\%) dan lansia yang melakukan aktifitas fisik $<3$ kali seminggu $(53 \%)$.

\section{B. ANALISIS BIVARIAT}

Tabel 2. Hubungan Pola Konsumsi Garam, Indeks Masa tubuh, Kebiasaan Merokok, Aktifitas Fisik dengan Kejadian Hipertensi pada Lansia

\begin{tabular}{|c|c|c|c|c|c|c|c|}
\hline \multirow{3}{*}{ Variabel } & \multicolumn{6}{|c|}{ Kejadian Hipertensi } & \multirow{3}{*}{$\begin{array}{c}(p- \\
\text { value })\end{array}$} \\
\hline & \multicolumn{2}{|c|}{ Hipertensi } & \multicolumn{2}{|c|}{$\begin{array}{c}\text { Tidak } \\
\text { hipertensi }\end{array}$} & \multirow[t]{2}{*}{$\mathbf{n}$} & \multirow[t]{2}{*}{$\%$} & \\
\hline & $\mathbf{n}$ & $\%$ & $\mathbf{n}$ & $\%$ & & & \\
\hline \multicolumn{7}{|c|}{ Riwayat Hipertensi } & \multirow{3}{*}{0,001} \\
\hline Ada & 93 & 76,2 & 29 & 23,8 & 122 & 100 & \\
\hline Tidak ada & 10 & 18,5 & 44 & 81,5 & 54 & 100 & \\
\hline \multicolumn{7}{|c|}{ Pola Konsumsi Garam } & \multirow{3}{*}{0,001} \\
\hline$\geq 1 \mathrm{sdt}$ & 63 & 50,4 & 62 & 49,6 & 125 & 100 & \\
\hline$<1 \mathrm{sdt}$ & 40 & 78,4 & 11 & 21,6 & 51 & 100 & \\
\hline \multicolumn{7}{|c|}{ Indeks Masa Tubuh } & \multirow{3}{*}{0,003} \\
\hline Obesitas & 63 & 70,0 & 27 & 30,0 & 90 & 100 & \\
\hline Tdk obesitas & 40 & 50,3 & 46 & 35,7 & 86 & 100 & \\
\hline \multicolumn{7}{|c|}{ Kebiasaan Merokok } & \multirow{3}{*}{0,015} \\
\hline Ya ( $\geq 1$ btg/hari) & 64 & 67,4 & 31 & 32,6 & 95 & 100 & \\
\hline Tidak & 39 & 48,1 & 42 & 51,9 & 81 & 100 & \\
\hline \multicolumn{7}{|l|}{ Aktifitas Fisik } & \multirow{3}{*}{0,009} \\
\hline$\geq 3 \mathrm{kali}$ & 45 & 72,6 & 17 & 27,4 & 62 & 100 & \\
\hline$<3 \mathrm{kali}$ & 58 & 50,9 & 56 & 49,1 & 114 & 100 & \\
\hline
\end{tabular}

Pada tabel 2 didapatkan riwayat lansia yang memiliki kejadian hipertensi 93 orang, lansia yang tidak memiliki riwayat hipertensi 10 orang. Analisis didapatkan $p$-value $=0,001<0,005$. Lansia yang mengkonsumsi $\geq 1$ sendok teh/ hari dengan kejadian hipertensi yaitu 63 orang $(50,4 \%)$ dan $<1$ sendok teh/ hari dengan kejadian hipertensi yaitu 40 orang $(78,4 \%)$ dengan analisis nilai $p$-value $=0,001<0,05$. Lansia yang obesitas dengan kejadian hipertensi yaitu 63 orang $(70,0 \%)$ dan lansia yang tidak obesitas dengan kejadian hipertensi yaitu 40 orang $(50,3 \%)$ dengan analisis nilai $p$-value $=0,003<0,05$. Lansia yang memiliki kebiasaan merokok dengan kejadian hipertensi yaitu 64 orang $(67,4 \%)$ dan lansia yang tidak memiliki kebiasaan merokok dengan kejadian hipertensi yaitu 39 orang $(48,1 \%)$ dengan analisis nilai $p$-value $=0,015<0,05$ dan lansia yang aktifitas fisik $\geq 3$ kali dengan kejadian hipertensi yaitu 48 orang $(72,6 \%)$ dan lansia yang beraktifitas fisik $<3$ kali dengan kejadian hipertensi yaitu 58 orang $(50,9 \%)$ dengan analisis nilai $p$-value $=0,009<0,05$.

Variabel yang masuk ke dalam permodelan multivariat setelah dilakukan seleksi bivariat adalah Riwayat hipertensi, Indeks Masa Tubuh, pola asupan garam, rokok dan aktifitas fisik dengan nilai $p$-value $\leq 0,25$. Berdasarkan pada permodelan multivariat menunjukkan risiko yang bermakna dengan $p$-value $<0,05$ yaitu Riwayat hipertensi, Indeks Masa Tubuh, pola 
asupan garam, rokok dan aktifitas fisik dan semua faktor risiko mengalami perubahan OR $10 \%$ sehingga dimasukkan kembali kedalam permodelan.

\section{ANALISIS MULTIVARIAT}

\section{Tabel 3. Faktor-faktor Dominan yang Mempengaruhi Kejadian Hipertensi pada Lansia}

\begin{tabular}{lcccc}
\hline \multirow{1}{*}{ Variabel } & p-value & \multirow{2}{*}{ OR } & \multicolumn{2}{c}{ CI 95\% } \\
\cline { 4 - 5 } & 0,001 & 13,3 & 5,747 & 30,930 \\
\hline $\begin{array}{l}\text { Riwayat } \\
\text { Hipertensi }\end{array}$ & 0,109 & 2,4 & 0,823 & 6,854 \\
\hline $\begin{array}{l}\text { Pola Konsumsi } \\
\text { Garam }\end{array}$ & 0,505 & 0,6 & 0,145 & 2,584 \\
\hline $\begin{array}{l}\text { Indeks Masa } \\
\text { Tubuh }\end{array}$ & 0,473 & 1,6 & 0,436 & 5,997 \\
\hline $\begin{array}{l}\text { Kebiasaan } \\
\text { Merokok }\end{array}$ & 0,312 & 1,7 & 0,618 & 4,515 \\
\hline Aktifitas fisik & & & & \\
\hline
\end{tabular}

Berdasarkan tabel 3 di atas adapun variabel yang berhubungan signifikan yaitu variabel riwayat hipertensi dengan $p$-value 0,001 $(<0,05)$, OR 13,3 CI 95\% $(5,74-30,93)$.

\section{PEMBAHASAN}

Pada penelitian ini ditemukan bahwa riwayat hipertensi lebih berisiko 13 kali terkena hipertensi dibandingkan tidak memiliki riwayat hipertensi. Menurut Black dan Hawks dalam (Syaifuddin, 2006) seseorang yang mempunyai riwayat hipertensi pada keluarga akan mempunyai risiko yang lebih besar untuk mengalami hipertensi. Hal ini terjadi karena seseorang yang mempunyai riwayat keluarga hipertensi beberapa gennya akan berinteraksi dengan lingkungan dan menyebabkan peningkatan tekanan darah. Peran faktor genetik terhdap timbulnya hipertensi terbukti dengan ditemukannya kejadian bahwa hipertensi lebih banyak pada kembar monozigot (satu sel telur) dari pada heterozigot (berbeda sel telur). Seorang penderita yang mempunyai sifat genetik hipertensi apabila dibiarkan secara alamiah tanpa intervensi terapi, bersama dengan lingkungannya akan menyebabkan hipertensinya berkembang dan dalam waktu sekitar 30 atau 50 tahun akan timbul tanda dan gejala (Sutanto, 2010). Keluarga yang memiliki hipertensi dan penyakit jantung meningkatkan resiko hipertenis 2-5 kali lipat. Jika seorang dari orang tua mempunyai hipertensi maka sepanjang hidup mempunyai $25 \%$ kemungkinan mendapatkan hipertensi pula. Jika kedua orang tua mempunyai hipertensi, maka kemungkinan mendapatkan hipertensi tersebut $60 \%$ (Sugiharto, 2007).

\section{SIMPULAN}

Menurut hasil penelitian yang dilakukan di wilayah kerja Puskesmas Sidomulyo Kota Pekanbaru disimpulkan bahwa:

1. Faktor determinan terjadinya hipertensi pada lansia disebabkan oleh riwayat hipertensi.

2. Tidak ada hubungan antara Pola konsumsi garam, Indeks Masa Tubuh, Kebiasaan merokok dan aktifitas fisik dengan kejadian hipertensi pada lansia di Puskesmas Sidomulyo Kota Pekanbaru.

\section{SARAN}

Diharapkan kepada Petugas kesehatan diharapkan melakukan pemeriksaan rutin tekanan darah kepada lansia, memberikan informasi, edukasi serta promosi kesehatan tentang hipertensi.

\section{DAFTAR PUSTAKA}

Bustan, M.N. 2007. Epidemiologi Penyakit Tidak Menular. Jakarta: Rineka Cipta.

Hariwijaya, M.S. 2007. Pencegahan dan Pengobatan Penyakit Kronis. Bandung: EDSA Mahkota.

Hartono, B. 2011. Hipertensi Pembunuh DiamDiam. http://health.kompas.com/read/2011/05/16/ 02522321/HipertensiPembunuhDiamdiam.

Indriyani, W. N. 2009. Deteksi Dini Kolesterol, Hipertensi dan Stroke. Jakarta: Millestone.
Wahda, N. 2011. Menaklukan Hipertensi dan Diabetes. Yogyakarta: Multi Press.

Syaifuddin. 2006. Anatomi Fisiologi untuk Mahasiswa Keperawatan Ed-3. Jakarta: EGC.

Sutanto. 2010. Cekal (Cegah dan Tangkal) Penyakit Modern. Yogyakarta: CV. Andi.

Sugiharto, A. 2007. Faktor-faktor Risiko Hipertensi Grade II pada Masyarakat (Studi Kasus di Kabupaten Karanganyar. Doctoral Dissertation. Program Pascasarjana Universitas Diponegoro. 